\title{
Trophic resources of the bivalve, Venus verrucosa, in the Chausey archipelago (Normandy, France) determined by stable isotopes and fatty acids
}

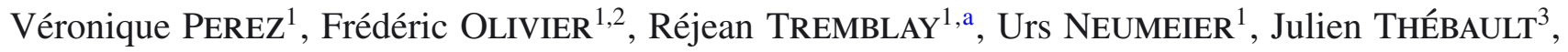 \\ Laurent CHAUVAUD ${ }^{3}$ and Tarik MEZIANE ${ }^{2}$ \\ 1 Institut des sciences de la mer, Université du Québec à Rimouski, 310 allée des Ursulines, Rimouski, Québec, G5L 3A1 Canada \\ 2 Muséum National d'Histoire Naturelle, DMPA, UMR 7208 BOREA CNRS-P6-MNHN-IRD, 61 rue Buffon, 75231 Paris, France \\ 3 Institut Universitaire Européen de la Mer, Université de Bretagne Occidentale, LEMAR, UMR 6539, UBO-IRD-CNRS, Technopôle \\ Brest-Iroise, rue Dumont d'Urville, 29280 Plouzané, France
}

Received 14 November 2012; Accepted 30 May 2013

\begin{abstract}
In the Chausey archipelago, growth of the burrowing bivalve Venus verrucosa (Mollusca: Veneridae) has been shown to be highly variable between closely located sites $(<1 \mathrm{~km})$. To explain this small-scale spatial variability, we tested the trophic hypothesis using both fatty acid markers, and carbon and nitrogen stable isotopes $\left(\delta^{13} \mathrm{C}\right.$ and $\left.\delta^{15} \mathrm{~N}\right)$. Environmental parameters, including substrate, were also analysed to discriminate their effects on potential trophic differences. Results of isotopic fractionation and lipid profiles of water column and digestive gland samples both showed a large contribution of phytoplankton to the diet of $V$. verrucosa. More surprisingly, the same results suggest that Phaeophyceae and Rhodophyceae macroalgae could contribute to the nutrition of $V$. verrucosa as dissolved exudates. Whereas site differences were not observed between the food sources of $V$. verrucosa, we showed that growth performance index was correlated to wave height. Thus, we hypothesized that the high local growth variability could be controlled by the hydrosedimentary dynamics. In addition, although no significant growth differences were found between intertidal and subtidal populations, better condition index and more total lipids were found in the digestive gland of intertidal $V$. verrucosa, suggesting potential compensatory growth mechanisms.
\end{abstract}

Keywords: Shell growth / Benthic filter feeder / Food sources / Stable isotope / Lipid / Macrotidal flat / Atlantic Ocean

\section{Introduction}

The burrowing venerid bivalve Venus verrucosa Linnaeus 1785 , also known as warty venus, colonizes coarse sediments of the the low intertidal zone and shallow waters to a depth of about $30 \mathrm{~m}$ in the eastern Atlantic, from Norway to South Africa, and in the Mediterranean Sea (Poppe and Goto 1993; Arneri et al. 1998). This species is of great commercial interest and particularly appreciated by European consumers (El-Menif et al. 2008). In Mauritania, as well as the Adriatic and Aegean Sea region, annual production can reach 500 t, although no reliable statistics are available (CNROP 1993; Arneri et al. 1998). In Europe, the yield is particularly large in France (Arneri et al. 1998; Tirado et al. 2003), where 95\% of total harvesting is done in the NormanoBreton Gulf (Pitel et al. 2001). In 1962 and 1975, more than $3500 \mathrm{t}$ were landed per year at Granville (Normandy), which was one of the largest French shellfish ports at this time. The stock collapsed twice

\footnotetext{
${ }^{a}$ Corresponding author: rejean_tremblay@uqar.qc.ca
}

between these two dates and, since 1993, annual production has decreased to less than $400 \mathrm{t}$ (Pitel et al. 2001).

In the Chausey archipelago (English Channel, Normandy, France), $V$. verrucosa is considered as an emblematic species of recreational and commercial fisheries (Godet 2008) and has a high heritage value locally. The gathering of such bivalves on foot constitutes one of the main activities for thousands of tourists that come every year to the tidal flats, and the number of fishers per day can reach 1500 during spring tides (Godet 2008). To maintain the current stock and continue to benefit from it, a sustainable management plan is needed. The first steps to efficiently protect this species are to make a stock assessment (Gosling 2003) and to obtain knowledge on its basic biology in relation to environmental constraints. Apart from some studies on toxicity (Romeo and GnassiaBarelli 1998; Gunsen et al. 2008; Pasquale et al. 2012), interactions with pathogens or parasites (Trigui El-Menif et al. 2005; Morton et al. 2011) and physical properties of the shell (Glover and Taylor 2010), data relating to the physiology of $V$. verrucosa are very sparse. Previous studies deal with 
growth (Arneri et al. 1998; El-Menif et al. 2008), reproduction (Djabali and Yahiaoui 1978; Barbin et al. 2003; Tirado et al. 2003; Siniscalchi et al. 2004) and food assimilation (Amouroux 1984).

In 2010, this lack of information stimulated the launch of a research program to study the population dynamics of $V$. verrucosa in some selected sites of the Chausey archipelago. Preliminary results revealed that the growth parameters of these populations differed at a very local spatial scale (less than $1 \mathrm{~km}$ ), which can only be partially explained by variations in the sediment granulometry (Gaillard 2010). Shellfish gathering is more intense in some areas of the islands than in others (Le Berre and Brigand 2011). Because V. verrucosa is a relatively slow-growing species (Peharda et al. 2010), the combined effects of low growth and high fishing pressure could increase the vulnerability of its populations. To avoid overexploitation, there is a need to understand the environmental causes of the growth variability, such as temperature, salinity, aerial exposure, hydrodynamics and stock density (Gosling 2003). All these factors closely impact the food supply, which is considered the most important factor for growth sustainability of bivalves (Thompson 1984; de Montaudouin 1996; Gosling 2003).

As secondary consumers are enriched in ${ }^{13} \mathrm{C}$ and ${ }^{15} \mathrm{~N}$ relative to their food supply or preys, stable isotopes of carbon $\left(\delta^{13} \mathrm{C}\right)$ and nitrogen $\left(\delta^{15} \mathrm{~N}\right)$ are useful tools to determine the assimilation of food on the long-term scale (Peterson and Fry 1987; Post 2002), as the turnover time of invertebrate tissues can take a few months (Lorrain et al. 2002; Nerot et al. 2012). Diet has also been extensively investigated with specific lipid markers of primary producers that can be tracked in the fatty acids (FAs) of consumers as they remain mostly unchanged through trophic pathways (Dalsgaard et al. 2003; Kelly and Scheibling 2012). In bivalves, FAs of digestive gland can be used to obtain insight into more recent food ingestion (Ezgeta-Balic et al. 2012) as this is the main organ of digestion and plays a significant role in storage of metabolic reserves (Gosling 2003).

The combination of these techniques (stable isotopes and FA composition) will allow us to determine the diet of $V$. verrucosa on an integrated interval of time (Ronconi et al. 2010), and help us to test the following hypotheses: (1) the quality and quantity of the food available for $V$. verrucosa are different between sites, (2) these differences are responsible for the local growth variability and (3) variability in environmental conditions (other than food availability) has a minor impact on growth differences.

\section{Materials and methods}

\section{Study site}

The Chausey archipelago, located in the Normano-Breton Gulf (Normandy, France), is exposed to an extreme tidal regime, with tidal ranges up to $14 \mathrm{~m}$ during spring tides. This fragmented environment includes about 1500 ha of soft sediment tidal flat (Toupoint et al. 2008).

Shellfish gathering on foot mainly concerns the tidal flats, where $V$. verrucosa is also more exposed to highly variable pressures of waves, emersion and temperature. We selected two contrasting areas (Fig. 1) where growth performance was either high (area 1) or low (area 2) (Gaillard 2010). An additional site was also selected in an area protected from fishing (area 3 ) in order to judge the potential impact of such activities. To consider environmental variation, samples were taken at two levels in each area, one in the intertidal zone (i) and one in the subtidal zone (s).

\section{Environmental conditions}

Temperature was monitored using probes (Onset Hobo Water Temp Pro V2 Data logger U22-001) buried $3 \mathrm{~cm}$ under the water-sediment interface, which recorded one measurement every 4 min for 3 months (July to September 2011) in each site. Sediment samples, previously collected using a shipeck grab in each subtidal site $(n=3)$, were rinsed with freshwater, dried, separated using the AFNOR standard (17 sieves), weighed and then analyzed using Gradistat 4.1 (Blott and Pye 2001).Wave recorders (RBR TWR-2050) were installed $0.25 \mathrm{~m}$ above the seabed during October 2011, when storms were frequent, to compare wave influence in the three subtidal sites. Pressure data were corrected to compensate for the frequency-dependent attenuation of pressure variations, and significant wave height $\mathrm{H}_{\mathrm{m} 0}$ was computed by spectral analysis using the standard method (Tucker and Pitt 2001).

\section{Venus verrucosa sampling}

In each area and level (intertidal and subtidal), twenty bivalves (mean height $=47.4 \pm 4 \mathrm{~mm} ; n=120$ ) were collected either by hand fishing on foot (intertidal) or by using a professional dredge with $2.5-\mathrm{cm}$ space between its rods. A few hours later, back at the laboratory, five specimens were selected according to their reproductive stage (no gametes visible with the naked eye). Digestive glands of the chosen individuals were separated from the organism for FA analyses and the rest of their tissues were crushed and used for isotopic analyses. All samples were frozen at $-20{ }^{\circ} \mathrm{C}$.

\section{Potential food sampling}

Three potential food sources of $V$. verrucosa were considered in this study, and characterized using two biochemical markers: stable isotopes and FAs. Firstly, we considered that intertidal and subtidal levels came into contact with similar bottom waters, so we collected 2-L samples $(n=5)$ in the three areas during flood tide just after bivalve sampling. In the laboratory, this water was filtered on Whatman $\mathrm{GF} / \mathrm{C}$ filters $(\varnothing=47 \mathrm{~mm})$. Secondly, the first $5 \mathrm{~mm}$ of the surficial sediments were collected using a cut off syringe with an inner diameter of $1.6 \mathrm{~cm}(n=5)$. Finally, the most abundant macroalgae were collected (Phaeophyceae: Ascophyllum nodosum, Fucus serratus, Fucus vesiculosus, Laminaria digitata, Pelvetia canaliculata, Sargassum muticum; Chlorophyceae: Enteromorpha sp., Ulva sp.; Rhodophyceae: Chondrus sp., Vertebrata lanosa (= Polysiphonia lanosa, epiphyte, 


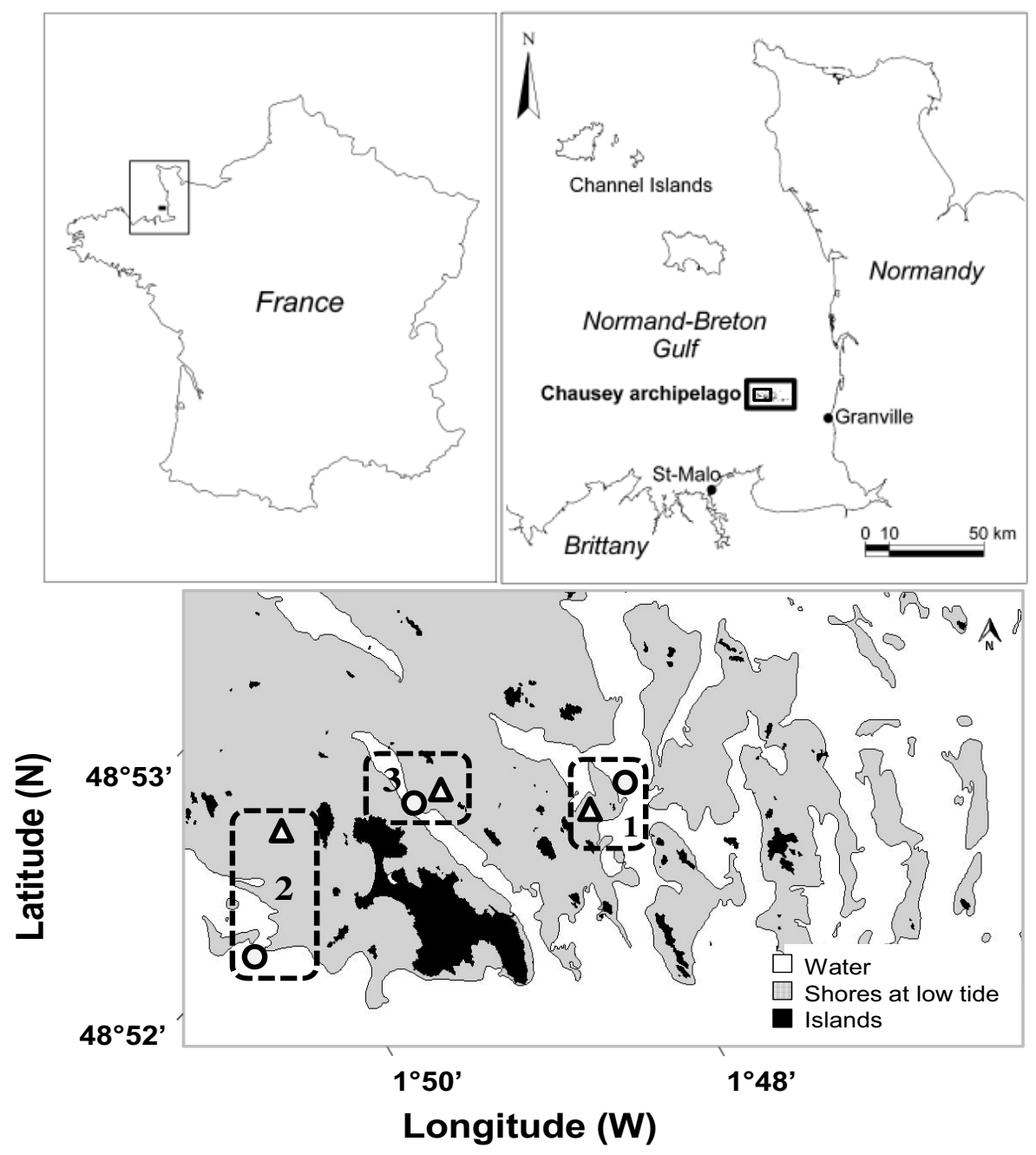

Fig. 1. Locations of the six study sites in the Chausey archipelago, open triangles and circles represent intertidal and subtidal levels, respectively; modified from Godet (2008).

most commonly associated with the Fucales algae Ascophyllum nodosum); as well as seagrass: Zostera marina. Three specimens were collected for each species, then, salt and epibionts were removed with Milli-Q water. All samples were lyophilized and kept at $-20{ }^{\circ} \mathrm{C}$ before analysis.

The quantities of food associated with the water column and sediments were estimated in each site by measuring chlorophyll $a$ and total particulate organic matter (TPOM). Chlorophyll $a$ was extracted from one GF/C filter, using acetone $90 \%$ for $16 \mathrm{~h}$, and the resulting solution was analyzed by spectrophotometer (Spectronic Genesys 2, Milton Roy) according to the equations of Jeffrey et al. (1997). TPOM was obtained by loss-on-ignition of dry mass (Higgins and Thiel 1988): previously dried samples $\left(60^{\circ} \mathrm{C}\right.$ for $\left.24 \mathrm{~h}\right)$ were weighed, then burned at $550{ }^{\circ} \mathrm{C}$ for $4 \mathrm{~h}$ and weighed again.

\section{Stable isotopes}

The isotopic ratio $(R)$ values of dried samples of $V$ verrucosa tissues and food sources $\left({ }^{13} \mathrm{C} /{ }^{12} \mathrm{C}\right.$ or $\left.{ }^{15} \mathrm{~N} /{ }^{14} \mathrm{~N}\right)$ were determined by the methods developed at the UC Davis
Stable Isotope Facility (Department of Plant Sciences, University of California at Davis, Davis, California), using a PDZ Europa ANCA-GSL elemental analyzer interfaced with a PDZ Europa 20-20 isotope ratio mass spectrometer (Sercon Ltd., Cheshire, UK), and are reported in standard delta notation $\left(\delta^{13} \mathrm{C}\right.$ or $\left.\delta^{15} \mathrm{~N}\right)$, in parts per thousand $(\% 0)$ :

$$
\delta^{13} \mathrm{C} \text { or } \delta^{15} \mathrm{~N}=\left[\left(R_{\text {sample }} / R_{\text {standard }}\right)-1\right] \times 1000 .
$$

Two different standards were used for the analysis, selected to be compositionally similar to the samples being analyzed and calibrated against NIST Standard Reference Materials (IAEAN1, IAEA-N2, IAEA-N3, USGS-40, and USGS-41). The standard deviations of the ratios are equal to $0.2 \%$ for $\delta^{13} \mathrm{C}$ and $0.3 \%$ for $\delta^{15} \mathrm{~N}$. Sediment samples were first decarbonated with a solution of $10 \% \mathrm{HCl}$ and dried at $60{ }^{\circ} \mathrm{C}$ for $24 \mathrm{~h}$.

\section{Fatty acid analyses}

Around $100 \mathrm{mg}$ in freeze-dried weight (FDW) of digestive glands and $500 \mathrm{mg}$ in FDW of macroalgae, seagrass and 
suspended particulate organic matter from the water column or sediment were used for FA analysis. These samples were processed using a slightly modified Bligh and Dyer (1959) method. Extraction, saponification of FAs and transformation to methylesters were done as described in Meziane and Tsuchiya (2002). Gas chromatography (GC; Varian CP-3800 with a flame ionization detector) was used to separate and quantify the FAs using helium as a carrier gas in a Supelco OMEGAWAX 320 column $(30 \mathrm{~m} \times 0.32 \mathrm{~mm}$ internal diameter, $0.25 \mu \mathrm{m}$ film thickness). After the injection of $1 \mu \mathrm{l}$ of sample at $60{ }^{\circ} \mathrm{C}$, the temperature was raised to $150{ }^{\circ} \mathrm{C}$ at $40{ }^{\circ} \mathrm{C} \mathrm{min}-1$, then to $240{ }^{\circ} \mathrm{C}$ (held $14 \mathrm{~min}$ ) at $3{ }^{\circ} \mathrm{C} \mathrm{min}-1$ (Mortillaro et al. 2011). Two methods were used to identify peaks of FAs: (1) comparison of their retention time with a commercial standard (SupelcoInc) and (2) and identification with a Gas Chromatography-Mass Spectrometer (GC-MS; ThermoFinnigan TRACE DSQ).

\section{Biometry and sclerochronology}

The shell of all the $V$. verrucosa were cleaned, dried, weighed and measured for length (anterior to posterior margin), width and height (axis of the maximum growth) using a vernier caliper.

Condition index (CI) was calculated for all specimens $(n=120)$ using the total freeze-dried weight (lyophilized for $48 \mathrm{~h}$ ) on the shell weight.

All shells were prepared and sliced using the same method and material as Royer et al. (2013), except for the following differences: hells were ground to a thickness of about $800 \mu \mathrm{m}$ and polished with only $3 \mu \mathrm{m} \mathrm{Al}_{2} \mathrm{O}_{3}$. A mosaic of fifteen images taken with a Hamamatsu C4742-95 digital camera connected to a binocular Leica MZ16 FM was assembled using Axiovision software (AxioVC40 V4.8.2.0). For each individual, the straight distances were measured from the umbo to each growth line, i.e., height " $h 1$ " at 1 year ("h" age-1), 5 years, and 9 years, throughout the life of the specimens, using the software Image J $1.45 \mathrm{~s}$. The von Bertalanffy growth function, $L_{(\mathrm{t})}=L_{\infty}\left[1-\mathrm{e}^{[-K(t-t o)]}\right]$, where $L_{\infty}$ is asymptotic shell length ("h", $\mathrm{mm}$ ), $K$ the growth coefficient $\left(\right.$ year $^{-1}$ ) and $t_{0}$ (year) the theoretical age at zero length, was chosen to predict length as a function of age, as it is commonly used to describe bivalve growth (Dang et al. 2010), this is suitable for $V$. verrucosa individual shell increments. The growth performance index $\left(\varphi^{\prime}\right)$, calculated using the previous parameters: $\varphi^{\prime}=2 \log \left(L_{\infty}\right)+$ $\log (K)$ after Pauly and Munro (1984), was obtained using a program written by Thomas Brey http://www.thomasbrey. de/science/virtualhandbook/spreadsheets/index.html using the growth model fit to size-at-age.

\section{Statistical analyses}

Univariate variables (Chl $a$, TPOM, growth parameters, $\delta^{13} \mathrm{C}$ and $\delta^{15} \mathrm{~N}$ of clam tissues, quantity of lipids and condition index) were compared using one-way ANOVA as a function of the three areas, or two-way ANOVA as a function of the three areas, the two bathymetric levels and their interactions.

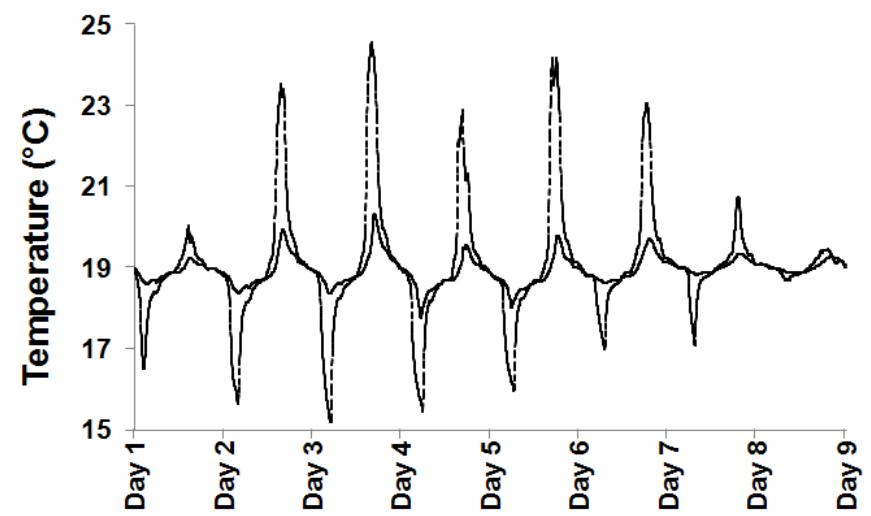

Fig. 2. Seawater temperature time series during spring tide (tidal range above $12 \mathrm{~m}$ ), data were collected in area 3 (September 28th to October 5th 2011), dashed and solid lines correspond to intertidal and subtidal levels, respectively.

The assumption of homoscedasticity was verified visually by the spread of residuals, as suggested by Quinn and Keough (2002), normality was tested by a Shapiro-Wilk test and data were transformed (logarithm, square root or exponential) when necessary. A posteriori comparisons were made using Tukey's test. When transformation could not normalize data or eliminate heteroscedasticity, a Kruskal-Wallis test was performed and a posteriori comparisons made using a Wilcoxon pairwise test. These statistical analyses were done using JMP ${ }^{\circledR} 20077.0$ and $\mathrm{R}^{\complement}$-2.13.0.

A distance-based permutational multivariate analysis of variance was used to compare multivariate variables (sediment granulometry and FA profiles). Assumptions of homoscedasticity were verified with a PERMDISP test, and data were transformed when necessary (arcsine transformation) (Sokal and Rohlf 1995), and then a PERMANOVA (9999 permutations) was performed. A posteriori comparisons were done using a PERMANOVA pairwise test. To analyze the similarity between the profiles, non-metric multi-dimensional scaling (nMDS) and SIMPER analysis were performed, using either a Bray-Curtis similarity matrix (FA profiles) or Euclidean distance (sediment granulometry). These statistical analyses were done under PRIMER 6 6.1.12 and PERMANOVA+ 1.0.2.

\section{Results}

\section{Environmental parameters}

Between all areas from the same bathymetric level, the mean temperature over the summer differed by less than $0.1{ }^{\circ} \mathrm{C}$, which should have a minor biological impact on bivalves. Temperature varied between 14.5 and $24.9^{\circ} \mathrm{C}$ in intertidal and between $16.2{ }^{\circ} \mathrm{C}$ and $19.8{ }^{\circ} \mathrm{C}$ in subtidal areas. During a typical spring tide, individuals living on the tidal flats were logically exposed to a wider range of temperature, as much as $9{ }^{\circ} \mathrm{C}$ twice a day (Fig. 2), and to temperatures exceeding $20^{\circ} \mathrm{C}$ during $8 \pm 1 \%$ of the time. Such thermal shocks were not observed for subtidal clams.

The wave heights were significantly different between the three areas, they were highest and variable in area 2 , smaller and variable in area 1 , and smallest and more constant in area 3 
Table 1. Grain size fractions in each area, at each bathymetric level (mean percent \pm standard deviation).

\begin{tabular}{lcccccc}
\hline \multirow{2}{*}{ Grain size } & \multicolumn{2}{c}{ Area 2 } & \multicolumn{2}{c}{ Area 1 } & \multicolumn{2}{c}{ Area 3 } \\
\cline { 2 - 7 } & Intertidal & Subtidal & Intertidal & Subtidal & Intertidal & Subtidal \\
\hline Gravel & $40.1 \pm 7.7$ & $17.0 \pm 15.3$ & $38.2 \pm 5.6$ & $23.8 \pm 8.9$ & $5.1 \pm 3.9$ & $12.9 \pm 2.4$ \\
Very coarse sand & $25.9 \pm 9.9$ & $21.2 \pm 17.3$ & $19.6 \pm 0.6$ & $21.8 \pm 9.7$ & $13.7 \pm 2.1$ & $14.6 \pm 4.7$ \\
Coarse sand & $14.3 \pm 8.0$ & $14.8 \pm 5.9$ & $14.1 \pm 0.9$ & $18.2 \pm 3.8$ & $19.2 \pm 5.1$ & $17.5 \pm 7.0$ \\
Medium sand & $7.1 \pm 3.2$ & $30.4 \pm 24.9$ & $18.3 \pm 3.2$ & $18.0 \pm 5.4$ & $27.4 \pm 5.2$ & $30.7 \pm 4.5$ \\
Fine sand & $7.2 \pm 8.4$ & $13.4 \pm 9.0$ & $8.2 \pm 2.1$ & $12.6 \pm 10.5$ & $30.7 \pm 6.0$ & $22.7 \pm 14.3$ \\
Very fine sand & $3.1 \pm 2.7$ & $2.4 \pm 0.9$ & $1.1 \pm 0.6$ & $4.6 \pm 5.8$ & $3.2 \pm 0.9$ & $1.3 \pm 1.0$ \\
Silt & $2.2 \pm 2.7$ & $0.7 \pm 0.4$ & $0.4 \pm 0.2$ & $1.0 \pm 0.7$ & $0.8 \pm 0.3$ & $0.4 \pm 0.3$ \\
\hline
\end{tabular}

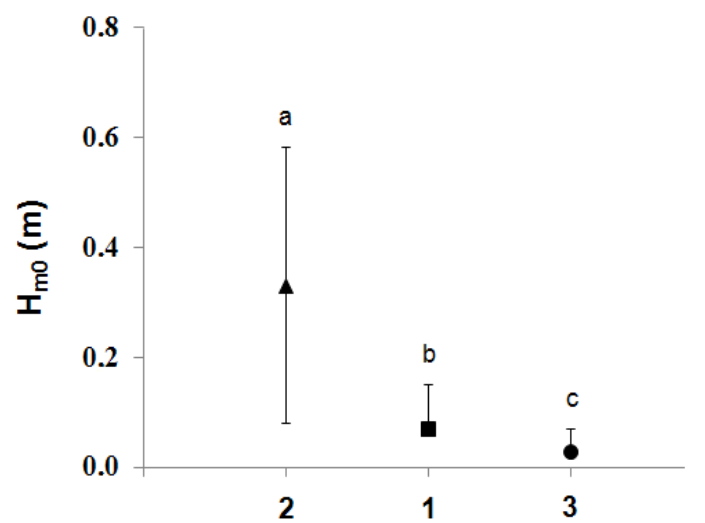

Fig. 3. Average significant wave heights calculated by the spectral methods $\left(H_{\mathrm{m} 0}\right) \pm$ standard deviation in area 1 to 3 (x-axis); letters indicate significantly different groups (Wilcoxon pairwise test).

(Kruskal-Wallis test: $\chi^{2}=2928.96, p<0.0001$; Wilcoxonpairwise test, $p<0.0001$ ) (Fig. 3). Intertidal sediments were more gravelly than subtidal ones, which is a sign of stronger hydrodynamics, except for in area 3 (Table 1). There was a gradient of decreasing particle size from area 2 to area 1 (Table 1), area 3 differing from the other areas (two-way PERMANOVA, pseudo- $\left.F_{(2,12)}=4.560, p=0.007\right)$, with no interaction between area and bathymetric levels (two-way PERMANOVA, pseudo- $\left.F_{(2,12)}=2.380, p=0.052\right)$.

\section{Food availability}

TPOM and chlorophyll $a$ were compared between areas, based on samples from the water column, and between areas and bathymetric levels for the sediment samples. The quantity of TPOM in the water column did not differ between areas $\left(\right.$ mean $=1.3 \pm 0.3 \mathrm{mg} \mathrm{L}^{-1}$, one-way ANOVA, $F_{(2,14)}=1.9$, $p=0.192)$, but there was significantly more chlorophyll $a$ in area $2\left(3.7 \pm 0.3 \mu \mathrm{g} \mathrm{L}^{-1}\right)$ than in area $1\left(2.7 \pm 0.3 \mu \mathrm{g} \mathrm{L}^{-1}\right.$; one-way ANOVA, $F_{(2,14)}=7.4, p=0.008$; Tukey's HSD, $p=0.006)$. Area 3 values were between those of area 2 and area 1 , with a mean of $3.3 \pm 0.2 \mu \mathrm{g} \mathrm{L}^{-1}$. For the surficial sediment TPOM, we found a significant interaction between area and bathymetric level but with no clear pattern (two-way ANOVA, $\left.F_{(2,24)}=15.5, p<0.0001\right)$. TPOM values varied from $172 \pm 82 \mathrm{mg} \mathrm{m}^{-2}$ in area 1 (subtidal) to $474 \pm 143 \mathrm{mg} \mathrm{m}^{-2}$ in area 2 (intertidal). Chl $a$ values in the surficial sediments differed significantly according to both area (two-way ANOVA,
$\left.F_{(2,24)}=19.1, p<0.0001\right)$ and bathymetric level (two-way ANOVA, $F_{(1,24)}=13.7, p=0,005$; Tukey's HSD, $p=0.006$ ). Chl $a$ concentrations were highest in area $2\left(215 \pm 101 \mathrm{mg} \mathrm{m}^{-2}\right)$ compared to area $1\left(116 \pm 54 \mathrm{mg} \mathrm{m}^{-2}\right.$; Tukey's HSD, $p=$ $0.005)$ and to area $3\left(64 \pm 43 \mathrm{mg} \mathrm{m}^{-2}\right.$; Tukey's HSD, $p<$ 0.0001). Between the two bathymetric levels, there was more chlorophyll $a$ in intertidal $\left(167 \pm 100 \mathrm{mg} \mathrm{m}^{-2}\right)$ than in subtidal surficial sediments $\left(96 \pm 73 \mathrm{mg} \mathrm{m}^{-2}\right)$ and no area $\times$ bathymetric level interaction was found (two-way ANOVA, $F_{(2,24)}=0.2$, $p=0.852$ ).

\section{Growth}

An interaction between the "area" and "bathymetric" factors affected the height of $V$. verrucosa at 1 year (h 1 , age one year, first winter rings on shells) and 5 years (h 5), although no clear trend could be identified at these ages (Table 2). The same interaction was found for the $K$ coefficient in the von Bertalanffy growth function, but a posteriori comparisons were not significant. For the 9-year heights (h 9), data were pooled per area to obtain sufficient replicates $(n=55)$ to perform statistical analyses. In area 3 (no fishing, finer sand), the growth of $V$. verrucosa was significantly higher in terms of mean maximum size, i.e., shell height $\left(L_{\infty},\right)$, and annual growth rate $\left(\varphi^{\prime}\right)$ (Table 2$)$.

\section{Stable isotopes}

No significant differences were found between $\delta^{15} \mathrm{~N}$ in the different tissue samples, indicating similarity in the trophic levels (two-way ANOVA, $p>0.05$ for area, bathymetric level and their interactions). Corresponding $\delta^{13} \mathrm{C}$ ratios varied between $-21.1 \%$ and $-20.0 \%$, and we observed a significant interaction between area and bathymetric level (two-way ANOVA, $F_{(2,12)}=6.580, p=0.012$ ). This suggests that different sources of carbon were used for food but, as no clear pattern could be observed and values were very similar, we considered all clam samples as belonging to the same group (Fig. 4).

Seagrass, Chlorophyceae (Ulva sp., Enteromorpha sp.) and sediment were excluded as potential food sources for $V$. verrucosa. Sediment had highly variable values (Fig. 4), but these were still out of the range of the theoretical isotopic fractionation (TIF, McCutchan et al. 2003) of the V. verrucosa in this study: $0.4 \%$ for $\delta^{13} \mathrm{C}$ and $2.3 \%$ for $\delta^{15} \mathrm{~N}$. Based on the TIF values, $V$. verrucosa is likely to feed on a water column 
Table 2. Growth parameters (mean \pm standard deviation) of Venus verrucosa from the different sites. h: shell height (in mm), e.g., "h 1" (age one year: first winter rings of shells), different superscript letters indicate significant differences at $p<0.05$ according to two-way ANOVA, as a function of the three areas $(1,2,3)$, the two bathymetric levels $(i$ : intertidal and $s$ : subtidal) and their interactions followed by a posteriori comparisons made with Tukey's test.

\begin{tabular}{|c|c|c|c|c|c|}
\hline \multirow[b]{2}{*}{ Variable } & \multirow[b]{2}{*}{ ANOVA } & \multirow[b]{2}{*}{$p$} & \multicolumn{3}{|c|}{ Post-hoc tests } \\
\hline & & & Area 2 & Area 1 & Area 3 \\
\hline \multirow{2}{*}{$\begin{array}{c}\text { h } 1(\mathrm{~mm}) \\
\text { age one year }\end{array}$} & Area & 0.545 & \multirow{2}{*}{$\begin{array}{l}\text { (i) } 6 \pm 2^{\mathrm{ab}} \\
\text { (s) } 7 \pm 3^{\mathrm{ab}}\end{array}$} & \multirow{2}{*}{$\begin{array}{l}\text { (i) } 6 \pm 2^{\mathrm{b}} \\
\text { (s) } 8 \pm 3^{\mathrm{a}}\end{array}$} & \multirow{2}{*}{$\begin{array}{l}\text { (i) } 7 \pm 1^{\mathrm{a}} \\
\text { (s) } 6 \pm 3^{\mathrm{ab}}\end{array}$} \\
\hline & $\begin{array}{c}\text { Bathy. } \\
\text { Area } \times \text { Bathy. }\end{array}$ & $\begin{array}{l}0.072 \\
\mathbf{0 . 0 1 7}\end{array}$ & & & \\
\hline \multirow{3}{*}{$\begin{array}{l}\text { h } 5(\mathrm{~mm}) \\
\text { age five years }\end{array}$} & Area & 0.158 & \multirow{3}{*}{$\begin{array}{l}\text { (i) } 30 \pm 3^{\mathrm{ab}} \\
\text { (s) } 29 \pm 4^{\mathrm{b}}\end{array}$} & \multirow{3}{*}{$\begin{array}{l}\text { (i) } 32 \pm 3^{\mathrm{a}} \\
\text { (s) } 29 \pm 3^{\mathrm{b}}\end{array}$} & \multirow{3}{*}{$\begin{array}{l}\text { (i) } 30 \pm 3^{\mathrm{ab}} \\
\text { (s) } 30 \pm 4^{\mathrm{ab}}\end{array}$} \\
\hline & Bathy. & 0.037 & & & \\
\hline & Area $\times$ Bathy & 0.043 & & & \\
\hline $\begin{array}{c}\text { h } 9(\mathrm{~mm}) \\
\text { age nine years }\end{array}$ & Area & 0.024 & $39 \pm 3^{b}$ & $40 \pm 3^{\mathrm{ab}}$ & $41 \pm 3^{\mathrm{a}}$ \\
\hline \multirow{3}{*}{$K\left(\right.$ year $\left.^{-1}\right)$} & Area & 0.728 & \multirow{3}{*}{\multicolumn{3}{|c|}{$\mathrm{NS} \mathrm{K}_{\text {mean }}=0.35 \pm 0.25$}} \\
\hline & Bathy. & 0.180 & & & \\
\hline & Area $\times$ Bathy & 0.036 & & & \\
\hline \multirow{3}{*}{$L_{\infty}(\mathrm{mm})$} & Area & 0.001 & \multirow{2}{*}{$44 \pm 7^{b}$} & \multirow{3}{*}{$45 \pm 6^{\mathrm{b}}$} & \multirow[t]{3}{*}{$47 \pm 1^{\mathrm{a}}$} \\
\hline & Bathy. & $<0.001$ & & & \\
\hline & Area $\times$ Bathy & 0.084 & (i) $44 \pm 4^{\mathrm{b}}$ & & \\
\hline \multirow{3}{*}{$t_{0}$ (year) } & Area & $<0.001$ & \multirow{3}{*}{$-1.7 \pm 1.6^{\mathrm{b}}$} & \multirow{3}{*}{$-1.9 \pm 0.0^{\mathrm{b}}$} & \multirow{3}{*}{$-4.0 \pm 1.0^{\mathrm{a}}$} \\
\hline & Bathy. & 0.501 & & & \\
\hline & Area $\times$ Bathy & 0.542 & & & \\
\hline \multirow{3}{*}{$\varphi^{\prime}\left(\mathrm{mm}\right.$ year $\left.^{-1}\right)$} & Area & $<0.001$ & \multirow{3}{*}{$2.8 \pm 0.1^{\mathrm{b}}$} & \multirow{3}{*}{$2.8 \pm 0.2^{\mathrm{b}}$} & \multirow{3}{*}{$2.9 \pm 0.1^{\mathrm{a}}$} \\
\hline & Bathy. & 0.202 & & & \\
\hline & Area $\times$ Bathy. & 0.372 & & & \\
\hline
\end{tabular}

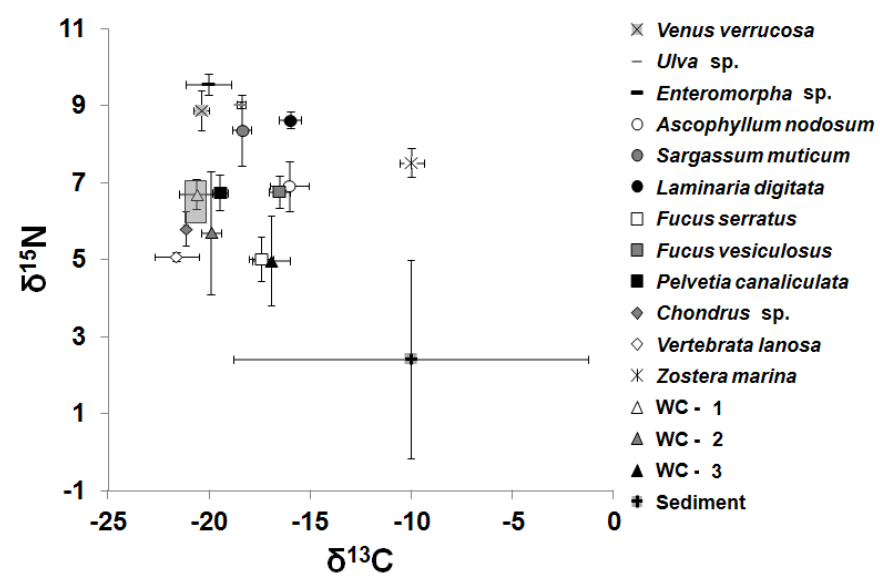

Fig. 4. Mean ( $\% 0 \pm$ standard deviation) $\delta^{13} \mathrm{C}$ and $\delta^{15} \mathrm{~N}$ of $V$. verrucosa and its potential food sources. WC: water column sampled in areas 1 , 2 and 3 (3: protected area). V. verrucosa food sources according to theoretical isotopic fractionation are shown by the grey zone.

source. These were highly variable in our study, probably due to the tidal cycle and to some local effects (Fig. 4). Phaeophyceae appear to mix with the water column signal, in particular for Pelvetia canaliculata. Rhodophyceae (Chondrus sp. and Vertebrata lanosa) and could also be in the range of the theoretical food source, being lower in ${ }^{13} \mathrm{C}$ and ${ }^{15} \mathrm{~N}$. Although the isotopic signal associated with water column samples was highly variable, related $C / N$ ratios fluctuated within the classic range for macroalgae $(4<C / N<10$, Meyers 1997), suggesting that they contribute to the water column.

\section{Lipids}

Total FA concentration (sum of all fatty acids) was significantly higher in the digestive glands of $V$. verrucosa in intertidal sites (two-way ANOVA, $F_{(2,24)}=4.4, p=0.047$, Table 3), with no significant differences between areas $(p=0.450)$ or for the interaction $(p=0.910)$.

The same pattern was found for the condition index $(\mathrm{CI})$, with no significant differences between areas $(p=0.374)$ or for the interaction $(p=0.941)$, but better CI in $V$. verrucosa from the intertidal level (two-way ANOVA, $F_{(2,114)}=13.9$, $p=0.0003$, Fig. 5).

FA profiles of digestive glands were different between the two bathymetric levels (two-way PERMANOVA, pseudo$F_{(1,24)}=3.8, p=0.013$, Table 3$)$, but not between areas $(p=0.509)$, and the interaction was not significant $(p=0.876)$. The SIMPER analysis showed that their composition was more than $88 \%$ similar. FA compositions of elements identified as a potential food source, either by the isotopic results or by similarity with digestive gland FAs of $V$. verrucosa are shown in Table 3 (water column, sediment, Phaeophycea and Rhodophyceae macroalgae). In the Phaeophyceae, only the Fucales group, which includes A. nodosum, $F$. serratus, $F$. vesiculosus and $P$. canaliculata, is shown in Table 3 , as their lipidic profiles were $90 \%$ similar. Main FAs of the Phaeophyceae (data not shown) were the same as the Fucales group (Table 3) with small variations in their relative proportions, less than 6\%, except for Sargassum muticum profiles, for which C16:0 was higher $(24.5 \pm 1.7 \%)$ and $\mathrm{C} 18: 1 \omega 9$ was lower $(7.6 \pm 0.4 \%)$ than that proportion. A significant difference was found between the lipid profiles associated with 
Table 3. Fatty acid composition (mean percent \pm standard deviation) of the digestive gland of Venus verrucosa in the intertidal and subtidal sites, water column, sediment, and seaweeds (Phaeo- and Rhodophyceae), bold type and letters indicate significantly different groups (Tukey's $\mathrm{HSD}, p>0.05)$; total fatty acids given in $\mathrm{mg}^{-1}$ dry mass.

\begin{tabular}{|c|c|c|c|c|c|c|c|c|c|c|}
\hline \multirow{2}{*}{ Fatty acids } & \multicolumn{2}{|c|}{ Digestive gland } & \multicolumn{3}{|c|}{ Water column } & \multicolumn{2}{|c|}{ Sediment } & \multirow{2}{*}{$\begin{array}{c}\text { Phaeophyceae } \\
\text { Fucales }\end{array}$} & \multicolumn{2}{|c|}{ Rhodophyceae } \\
\hline & Intertidal $^{\mathrm{a}}$ & Subtidal $^{\mathrm{b}}$ & $2^{\mathrm{a}}$ & $1^{\mathrm{b}}$ & $3^{\mathrm{c}}$ & Intertidal $^{\mathrm{a}}$ & Subtidal $^{\mathrm{b}}$ & & Vertebrata lanosa & Chondrus sp. \\
\hline \multicolumn{11}{|l|}{ Saturated } \\
\hline $\mathrm{C} 12: 0$ & 0 & 0 & $1.1 \pm 0.2$ & $0.9 \pm 0.1$ & $1.1 \pm 0.5$ & $0.6 \pm 0.4^{\mathrm{a}}$ & $2.4 \pm 0.4^{b}$ & 0 & 0 & $2.0 \pm 0.6$ \\
\hline $\mathrm{C} 14: 0$ & $8.8 \pm 1.4^{\mathrm{a}}$ & $6.8 \pm 1.0^{b}$ & $20.1 \pm 1.4^{\mathrm{ab}}$ & $19.0 \pm 0.8^{\mathrm{a}}$ & $21.0 \pm 1.1^{b}$ & $3.7 \pm 0.6^{\mathrm{a}}$ & $6.8 \pm 0.6^{b}$ & $10.5 \pm 1.0$ & $2.7 \pm 0.1$ & $18.7 \pm 2.3$ \\
\hline C15:0 & $0.5 \pm 0.1$ & $0.5 \pm 0.1$ & $0.8 \pm 0.1^{\mathrm{ab}}$ & $0.7 \pm 0.1^{\mathrm{a}}$ & $0.9 \pm 0.1^{\mathrm{b}}$ & $1.4 \pm 0.9$ & $1.4 \pm 0.9$ & $0.4 \pm 0.1$ & $0.4 \pm 0.0$ & $0.6 \pm 0.1$ \\
\hline C16:0 & $23.1 \pm 4.7$ & $21.5 \pm 2.5$ & $17.0 \pm 1.7$ & $17.0 \pm 0.9$ & $17.0 \pm 0.7$ & $25.5 \pm 3.3$ & $27.2 \pm 3.3$ & $14.4 \pm 2.1$ & $24.7 \pm 0.6$ & $55.2 \pm 3.8$ \\
\hline C20:0 & 0 & 0 & $1.4 \pm 0.1^{\mathrm{a}}$ & $1.2 \pm 0.1^{\mathrm{a}}$ & $1.0 \pm 0.1^{b}$ & $0.3 \pm 0.3$ & $0.5 \pm 0.3$ & $0.3 \pm 0.1$ & $0.2 \pm 0.0$ & 0 \\
\hline$\Sigma$ SFA & $36.5 \pm 7.1^{\mathrm{a}}$ & $32.9 \pm 4.5^{\mathrm{b}}$ & $44.0 \pm 4.6^{\mathrm{ab}}$ & $42.0 \pm 2.6^{\mathrm{a}}$ & $45.1 \pm 3.1^{\mathrm{b}}$ & $35.5 \pm 6.7^{\mathrm{a}}$ & $49.3 \pm 6.7^{b}$ & $26.6 \pm 3.8$ & $29.1 \pm 0.8$ & $78.3 \pm 7.3$ \\
\hline \multicolumn{11}{|l|}{ Branched } \\
\hline C15:0 (iso) & 0 & 0 & $0.4 \pm 0.1^{\mathrm{a}}$ & $0.4 \pm 0.1^{\mathrm{a}}$ & $0.7 \pm 0.2^{b}$ & $0.8 \pm 0.2^{\mathrm{a}}$ & $1.1 \pm 0.2^{b}$ & $0.0 \pm 0.0$ & $0.3 \pm 0.0$ & 0 \\
\hline C15:0 (anteiso) & 0 & 0 & $0.4 \pm 0.1^{\mathrm{a}}$ & $0.3 \pm 0.1^{\mathrm{a}}$ & $0.6 \pm 0.2^{b}$ & $\mathbf{0 . 7} \pm \mathbf{0 . 3 ^ { \mathrm { a } }}$ & $1.1 \pm 0.3^{b}$ & $0.0 \pm 0.1$ & $0.3 \pm 0.0$ & 0 \\
\hline$\Sigma$ Branched & 0 & 0 & $0.8 \pm 0.2^{\mathrm{a}}$ & $0.7 \pm 0.1^{\mathrm{a}}$ & $1.3 \pm 0.5^{b}$ & $1.5 \pm 0.7^{\mathrm{a}}$ & $2.2 \pm 0.5^{b}$ & $0.0 \pm 0.1$ & $0.6 \pm 0.0$ & 0 \\
\hline C14:1 & $1.9 \pm 0.4$ & $2.2 \pm 0.5$ & 0 & 0 & 0 & $0.1 \pm 0.2$ & $0.2 \pm 0.2$ & $0.1 \pm 0.1$ & 0 & 0 \\
\hline $\mathrm{C} 16: 1 \omega 9$ & $0.1 \pm 0.0^{\mathrm{a}}$ & $0.2 \pm 0.1^{b}$ & $1.4 \pm 0.2^{\mathrm{a}}$ & $1.0 \pm 0.1^{b}$ & $1.3 \pm 0.1^{\mathrm{a}}$ & $0.9 \pm 0.4$ & $1.2 \pm 0.4$ & $0.9 \pm 0.5$ & $1.4 \pm 0.3$ & $1.0 \pm 0.3$ \\
\hline $\mathrm{C} 16: 1 \omega 7$ & $10.0 \pm 1.3$ & $9.3 \pm 1.1$ & $15.0 \pm 0.8$ & $16.1 \pm 0.6$ & $14.9 \pm 1.4$ & $26.0 \pm 5.7^{\mathrm{a}}$ & $14.5 \pm 5.7^{\mathrm{b}}$ & $1.4 \pm 0.5$ & $9.3 \pm 1.0$ & $1.0 \pm 0.2$ \\
\hline $\mathrm{C} 18: 1 \omega 9$ & $1.4 \pm 0.3$ & $1.4 \pm 0.2$ & $2.4 \pm 0.4$ & $2.2 \pm 0.2$ & $2.0 \pm 0.3$ & $2.4 \pm 0.3$ & $2.7 \pm 0.3$ & $22.5 \pm 3.4$ & $4.1 \pm 0.1$ & $7.8 \pm 0.6$ \\
\hline $\mathrm{C} 18: 1 \omega 7$ & $5.7 \pm 0.9$ & $5.1 \pm 0.7$ & $2.0 \pm 0.2$ & $2.0 \pm 0.3$ & $2.4 \pm 0.4$ & $3.9 \pm 0.9$ & $3.2 \pm 0.7$ & $0.3 \pm 0.2$ & $10.5 \pm 0.6$ & $1.8 \pm 0.2$ \\
\hline $\mathrm{C} 20: 1 \omega 7$ & $1.4 \pm 0.3$ & $1.4 \pm 0.4$ & 0 & 0 & 0 & $0.2 \pm 0.2$ & $0.1 \pm 0.2$ & 0 & 0 & 0 \\
\hline$\Sigma \mathrm{MFA}$ & $20.5 \pm 3.2^{\mathrm{a}}$ & $19.5 \pm 3.0^{b}$ & $20.9 \pm 1.6$ & $21.3 \pm 1.2$ & $20.6 \pm 2.1$ & $33.5 \pm 7.5^{\mathrm{a}}$ & $21.9 \pm 7.5^{\mathrm{b}}$ & $25.2 \pm 4.6$ & $25.3 \pm 2.0$ & $11.5 \pm 1.3$ \\
\hline \multicolumn{11}{|l|}{ Polyunsaturated } \\
\hline $\mathrm{C} 16: 2 \omega 4$ & $0.9 \pm 0.1$ & $0.9 \pm 0.2$ & $2.0 \pm 0.1^{\mathrm{a}}$ & $1.7 \pm 0.1^{\mathrm{b}}$ & $1.8 \pm 0.2^{\mathrm{ab}}$ & $1.4 \pm 0.3^{\mathrm{a}}$ & $0.9 \pm 0.3^{b}$ & $0.1 \pm 0.1$ & $2.2 \pm 0.5$ & 0 \\
\hline $\mathrm{C} 16: 3 \omega 4$ & $0.5 \pm 0.1$ & $0.5 \pm 0.2$ & $1.0 \pm 0.2$ & $0.8 \pm 0.2$ & $0.8 \pm 0.2$ & $1.7 \pm 0.4$ & $1.6 \pm 0.4$ & $0.0 \pm 0.1$ & $0.5 \pm 0.0$ & 0 \\
\hline $\mathrm{C} 16: 4 \omega 1$ & $0.9 \pm 0.1^{\mathrm{a}}$ & $1.1 \pm 0.3^{\mathrm{b}}$ & $2.8 \pm 0.7$ & $1.9 \pm 0.5$ & $2.6 \pm 0.7$ & $0.4 \pm 0.2$ & $0.4 \pm 0.2$ & $0.0 \pm 0.0$ & 0 & 0 \\
\hline $\mathrm{C} 18: 2 \omega 6$ & $0.7 \pm 0.1$ & $0.7 \pm 0.1$ & $1.4 \pm 0.1$ & $1.3 \pm 0.1$ & $1.2 \pm 0.1$ & $1.5 \pm 0.6^{\mathrm{a}}$ & $1.0 \pm 0.6^{b}$ & $10.9 \pm 0.9$ & $3.3 \pm 0.1$ & $0.9 \pm 0.2$ \\
\hline $\mathrm{C} 18: 3 \omega 3$ & $0.7 \pm 0.1^{\mathrm{a}}$ & $0.8 \pm 0.1^{b}$ & $1.5 \pm 0.1^{\mathrm{a}}$ & $1.8 \pm 0.1^{b}$ & $1.1 \pm 0.1^{c}$ & $1.4 \pm 1.1$ & $0.7 \pm 1.1$ & $4.4 \pm 0.8$ & $2.5 \pm 0.6$ & 0 \\
\hline $\mathrm{C} 18: 4 \omega 3$ & $3.2 \pm 0.7$ & $3.5 \pm 0.7$ & $5.8 \pm 0.2^{\mathrm{a}}$ & $6.0 \pm 0.1^{a}$ & $4.6 \pm 0.2^{b}$ & $1.1 \pm 0.3$ & $1.2 \pm 0.3$ & $4.0 \pm 0.8$ & $1.2 \pm 0.4$ & 0 \\
\hline $\mathrm{C} 20: 5 \omega 3$ & $16.3 \pm 3.6$ & $18.6 \pm 3.4$ & $10.1 \pm 0.6$ & $11.4 \pm 0.7$ & $10.5 \pm 1.1$ & $7.0 \pm 3.1$ & $6.7 \pm 3.1$ & $7.1 \pm 0.9$ & $22.4 \pm 0.9$ & $2.7 \pm 0.5$ \\
\hline $\mathrm{C} 22: 2 \omega 9$ & $1.4 \pm 0.3^{\mathrm{a}}$ & $1.9 \pm 0.6^{b}$ & 0 & 0 & 0 & $0.1 \pm 0.3$ & $0.0 \pm 0.3$ & 0 & 0 & 0 \\
\hline $\mathrm{C} 22: 4 \omega 6$ & $0.9 \pm 0.2^{\mathrm{a}}$ & $1.2 \pm 0.2^{b}$ & 0 & 0 & 0 & 0 & 0 & 0 & 0 & 0 \\
\hline $\mathrm{C} 22: 5 \omega 3$ & $1.1 \pm 0.2^{\mathrm{a}}$ & $1.5 \pm 0.4^{b}$ & 0 & 0 & 0 & $0.4 \pm 0.2$ & $0.4 \pm 0.2$ & 0 & $0.2 \pm 0.0$ & 0 \\
\hline $\mathrm{C} 22: 6 \omega 3$ & $4.6 \pm 1.2^{\mathrm{a}}$ & $5.8 \pm 1.1^{\mathrm{b}}$ & $4.9 \pm 0.4^{\mathrm{a}}$ & $6.3 \pm 1.2^{b}$ & $5.2 \pm 1.3^{\mathrm{ab}}$ & $1.1 \pm 0.2$ & $0.9 \pm 0.2$ & $1.2 \pm 0.2$ & $0.8 \pm 0.5$ & 0 \\
\hline$\Sigma$ PUFA & $33.9 \pm 7.3^{\mathrm{a}}$ & $38.7 \pm 7.5^{\mathrm{b}}$ & $32.0 \pm 2.7^{\mathrm{ab}}$ & $33.7 \pm 3.1^{\mathrm{a}}$ & $30.0 \pm 4.2^{\mathrm{b}}$ & $19.2 \pm 8.6$ & $16.4 \pm 8.6$ & $44.2 \pm 6.0$ & $39.6 \pm 4.2$ & $9.2 \pm 2.4$ \\
\hline Total fatty acids & $41.6 \pm 9.4^{\mathrm{a}}$ & $34.2 \pm 7.1^{\mathrm{b}}$ & $30.3 \pm 5.4$ & $38.1 \pm 5.2$ & $27.7 \pm 11.7$ & $0.1 \pm 0.04^{\mathrm{a}}$ & $\mathbf{0 . 0 8} \pm \mathbf{0 . 0 3}^{\mathrm{b}}$ & $1.8 \pm 1.1$ & $0.8 \pm 0.1$ & $0.3 \pm 0.0$ \\
\hline
\end{tabular}

water column samples from the three areas (one-way PERMANOVA, pseudo- $F_{(2,12)}=4.1284, p=0.0003$, Table 3), but their similarities exceeded $92 \%$. The main FAs of the water column were C14:0, C16:0, C16:1 $\omega 7, \mathrm{C} 18: 4 \omega 3, \mathrm{C} 20: 5 \omega 3$ and C22:6 63 (Table 3).

The sources the most similar to digestive gland FA compositions were water column samples $(>67 \%)$, Vertebrata lanosa $(>68 \%)$ and Phaeophyceae ( $>46 \%)$, respectively. The sediment samples, as shown by isotopic markers, can be excluded as a direct potential source (Fig. 6). Contributions of important FAs associated with Phaeo- and Rhodophyceae macroalgae

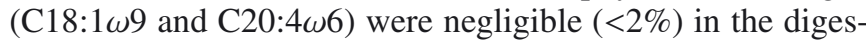
tive glands (Table 3). The FA profiles from the digestive glands of Venus verrucosa resembled those of the Phaeophyceae as shown by n-MDS analysis (Fig. 6).

\section{Discussion}

Our results clearly show that local-scale growth differences in $V$. verrucosa are not explained by differential trophic resources in the Chausey archipelago. In this study, long term (stable isotopes) or more recent food (FA profiles of the digestive glands) assimilations did not differ between sites. Food availability is a major factor influencing growth rates of bivalves (Richardson et al. 1980; Nerot et al. 2012). In the Mediterranean Sea, Arneri (1998) found better growth rates where the quantity of nutrients was higher in sites with similar temperatures, suggesting that food availability plays an important role in the growth of venerids. Moreover, no changes were found in the amount of TPOM between all sites, but the lowest growth rates observed in our work were associated with 


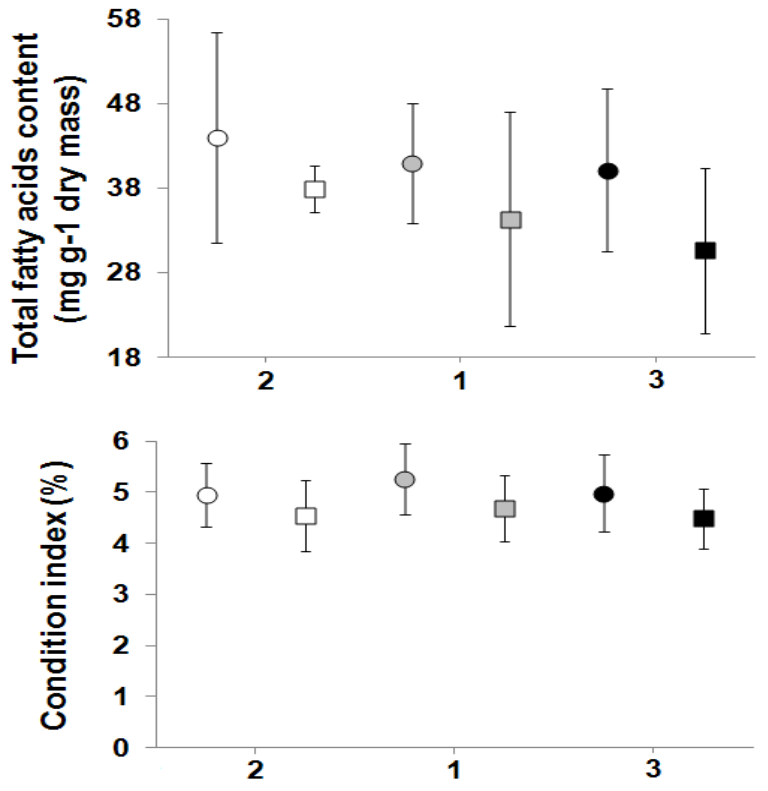

Fig. 5. Upper panel: total fatty acid content of the digestive gland ( \pm standard deviation) of $V$. verrucosa; lower panel: condition index $(\% \pm$ standard deviation) in area 1 to 3 ( $x$-axis). Circles or squares correspond intertidal and subtidal levels, respectively.

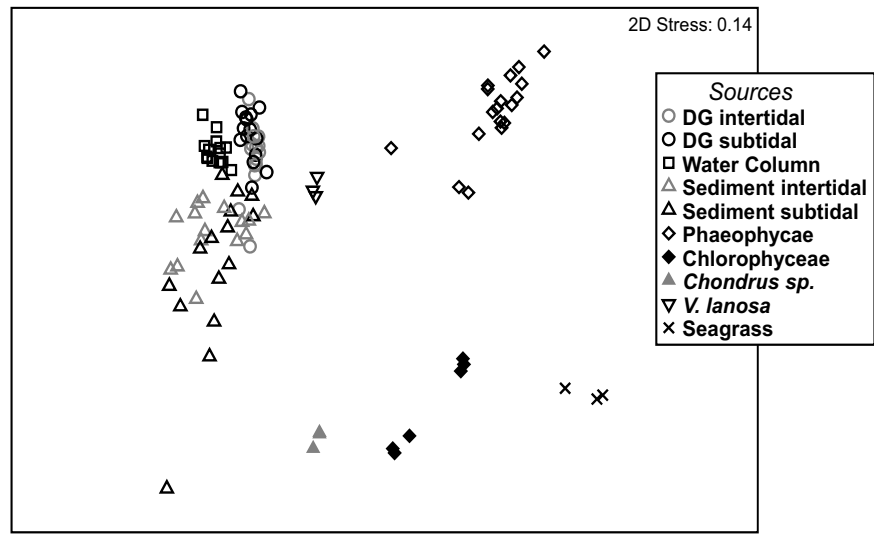

Fig. 6. Non-metric multi-dimensional scaling of the Bray-Curtis similarity matrix based on the relative abundance of fatty acid profiles associated with digestive gland (DG) of either intertidal or subtidal samples (O) and the potential food sources as water column ( $\square$ open square), sediment from either the intertidal or subtidal level ( $\Delta$ open triangle), Phaeophyceae ( $\diamond$ open losange), Chlorophyceae (plain losange), Chondrus sp. (Rhodophyceae, $\Delta$ plain triangle), Vertebrata lanosa (Rhodophyceae, open inverted triangle) and seagrass (x).

the areas that had the richest chlorophyll $a$ concentrations. All these indicators of food availability suggest that we cannot discriminate the growth rate differences of $V$. verrucosa observed in Chausey archipelago according to this factor.

Amongst other environmental factors that influence bivalve growth, salinity and density could be crucial, but the Chausey archipelago is located $17 \mathrm{~km}$ off Granville (on the coast of Normandy) and isolated from freshwater inputs (Royer et al. 2013), and the mean density of V. verrucosa seems very low (0.27 \pm 0.05 ind. $\mathrm{m}^{-2}$; Gaillard 2010), compared to the mean density in the "Rade de Brest" where a wider size range (from $5 \mathrm{~mm}$ to $60 \mathrm{~mm}$ ) was considered (4 to 14 ind. $\mathrm{m}^{-2}$, Pitel-Roudaut et al. 2006). Moreover, temperatures and emersion times were similar between areas with the same bathymetric level.

Height of waves was a highly variable parameter between the studied areas and it is well known that waves generate strong hydrodynamic benthic boundary layer stress (Vogel 1984; Dame 1996). Indeed, the slow-growing site was characterized by higher wave amplitudes, and its sediment contained larger sand grains. Whereas moderate levels of turbulence (e.g., area 3 in this study) can favour passive filterfeeding by decreasing the pumping activity of bivalves and also avoid food depletion, high turbulence levels often inhibit feeding processes due to a differential pressure between the exhalant and inhalant aperture of the siphon (Wildish and Saulnier 1993) and can induce shell closure (Wildish and Kristmanson 2005). For a filter-feeder, shell closure makes feeding impossible, which would reduce the potential energy input for $V$. verrucosa and might lead to a diminution in growth rate. Also, a strong hydrodynamic influence on sediment stability can dislodge the bivalves from their physical position (Rufino et al. 2010). These movements also induce the bivalves to rebury themselves, which can be costly in terms of energy (Urban 1994). In the Chausey archipelago, we suggest that the hydrosedimentary stress, which generates sediment instability, could have a major influence on $V$. verrucosa growth.

\section{Trophic resources}

Coupled approaches of isotopic and fatty acid analyses showed that Chausey V. verrucosa feeds mostly on pelagic microalgae but also that its diet is enriched in dissolved exudates of Rhodophyceae and Phaeophyceae macroalgae. The $V$. verrucosa diet could be inferred from stable isotope results, as each source showed a distinct signal (Riera et al. 2004). The content of the water column was identified as the main food source with the isotopic fractionation factor of $0.4 \%$ for $\delta^{13} \mathrm{C}$ and $2.3 \%$ for $\delta^{15} \mathrm{~N}$, which is a mean for aquatic animals (McCutchan et al. 2003; Belicka et al. 2012). From isotopic signals, sediments were excluded as a food source even if their FAs profiles showed similarity with those of digestive gland and water column samples. This could be explained by the prevalence of similar microalgae markers in both water and sediment samples, such as diatoms $(\mathrm{C} 16: 1 \omega 7$ and $\mathrm{C} 20: 5 \omega 3)$ and dinoflagellates $(\mathrm{C} 18: 4 \omega 3$ and $\mathrm{C} 22: 6 \omega 3$; Dalsgaard et al. 2003; Kelly and Scheibling 2012). The similarity between lipid profiles of $V$. verrucosa tissue and water column samples emphasize the conclusion that $V$. verrucosa is a strict filter-feeding species.

The benthic food web is supported by many sources of primary production (macroalgae, vascular plants, phytoplankton, etc.) and it can be difficult to distinguish their specific contributions when an organism has an omnivorous diet (Dalsgaard et al. 2003; Kelly and Scheibling 2012). We observed a great variation of stable isotopes in the suspended particulate organic matter of the water column. This variability could be caused by blooms of phytoplankton at a very local scale or by different particulate organic matter enrichment of $\delta^{13} \mathrm{C}$ from the water masses, depending on whether these come from 
inshore or offshore (Miller and Page 2012). One great challenge in characterizing the suspended particulate organic matter in the water column is to separate phytoplankton from macrophyte detritus (Michener and Kaufman 2007). The isotopic results suggest that Rhodophyceae and Phaeophyceae macroalgae, which are common in Chausey (Lami 1972), would excrete exudates that might be associated with the particulate organic matter of the water column. Phaeophycea and Rhodophycea macroalgae can secrete exudates that could play a significant role as a carbon source in nearshore systems (Alber and Valiela 1996; Fredriksen 2003; Gollety et al. 2010), either as aggregates or dissolved organic material, at various contribution levels (Cranford and Grant 1990; Alber and Valiela 1996). As these exudates might not be lipidic, this could explain why macroalgae traces are found in isotope signals of the water column and not in $V$. verrucosa. It is not the first time that $V$. verrucosa has been shown to assimilate dissolved exudates, especially when these originate from bacteria rather than phytoplankton (Amouroux 1984). Thus, there is still a need to understand the nature and the ecological roles of such macroalgal exudates.

\section{Mechanism of compensatory growth}

No growth differences could be observed between intertidal and subtidal $V$. verrucosa in this macrotidal environment (up to $14 \mathrm{~m}$, tidal range), although intertidal specimens were subjected to potential thermal (exposure up to $25^{\circ} \mathrm{C}$ with a $10{ }^{\circ} \mathrm{C}$ thermal range within $12 \mathrm{~h}$ ) and emersion stresses. The limits of thermal tolerance of this species are not welldefined, but it has been shown that the tidal cycle in temperate areas slows down the growth rate for many other bivalves, such as cockles (Richardson et al. 1980; de Montaudouin 1996) and mussels in temperate areas (Menai Strait, UK), in which growth is slower below $3{ }^{\circ} \mathrm{C}$ and above $20^{\circ} \mathrm{C}$ (Almada-Villela et al. 1982). Those lower growth rates could be related to other factors in the intertidal environment, such as physiological stress caused by high temperature variations, especially in macrotidal areas (Thompson 1984; Pernet et al. 2007). In the Mediterranean Sea, Arneri et al. (1998) hypothesized that high summer temperatures could inflate $V$. verrucosa metabolism and decrease growth performance. Emersion could also restrict access to food supply and affect condition index (de Montaudouin 1996). V. verrucosa showed the same growth performances in intertidal areas as in subtidal ones, but had higher total lipid concentrations in the digestive glands and better condition index in intertidal areas. These results could suggest that $V$. verrucosa can adapt its filtration rate during immersion in the intertidal zone to ingest more food than in the subtidal zone. Similar acclimatization patterns have already been observed on the cirriped Semibalanus balanoides and were also suggested in the cockle Cerastoderma edule (Richardson et al. 1980). This acclimatization pattern could be defined as a mechanism of compensatory growth, which is an energy supplementing adaptation resulting in greater nutritional input per unit immersion time in intertidal compared with subtidal individuals of the same population, as described by Gillmor (1982). These physiological trade-offs are complex (Bayne 2004) and better knowledge of $V$. verrucosa metabolism is needed to define this intertidal strategy.

\section{Conclusion}

Venus verrucosa appears to be a strict filter-feeder in the Chausey archipelago, feeding mainly on microalgae of the water column, but with the capacity to use carbon from dissolved exudates of Rhodo- or Phaeophycea macroalgae as food sources. These other carbon sources are probably easily available in this area, given the large abundance of these macroalgae. As $V$. verrucosa from different areas at the same intertidal level ingest a similar quantity and quality of food sources in the long term, we conclude that the hydrodynamic conditions generated by waves are the major factor controlling growth performance in this archipelago. Furthermore, mechanisms of compensatory growth were revealed in the intertidal populations. All this new knowledge on the physiology of $V$. verrucosa should be taken into account in sustainable management programs for the Chausey populations.

Acknowledgements. The authors would especially like to thank M.-F. Bernard, Y. Turgis (Syndicat Mixte Espaces littoraux de la Manche (SyMEL)) and J.-M. Mortillaro (MNHN) for helping us during the field work. We are also grateful to the fisherman P. Delacour and his crew for collecting warty venus specimens so close to the rocks! We thank C. Boinet and J. Fournier from the CRESCo (Dinard, France), E. Dabas from the LASAA/Lemar (Brest, France) and J. Granger for their technical support with dredge improvements, shell sample work and laboratory analyses. We would also like to thank L. Godet from Géolittomer (Nantes, France) and C. Hubas from the MNHN (Paris, France) for their great help with the figures. Financial support, including an MSc grant to V. Perez, was provided by National Agencies (Agence de l'eau, Seine Normandie AESN, SyMEL, Agence des Aires Marines Protégées) in the context of Marine Protected Areas in the Atlantic Arc (MAIA) project. Special thanks to the Réseau d'Aquaculture du Québec (RAQ) for providing complementary funds for meetings and symposium trips by scientists and students and also for technical support at the ISMER/UQAR. We are grateful to the Fonds de Recherche du Québec - Nature et Technologies (FQRNT) for providing a grant to V. Perez for a 8-month placement in MNHN Paris to do the fatty acid analyses.

\section{References}

Alber M., Valiela I., 1996, Utilization of microbial organic aggregates by bay scallops, Argopecten irradians (Lamarck). J. Exp. Mar. Biol. Ecol. 195, 71-89.

Almada-Villela P.C., Davenport J., Gruffydd L.D., 1982, The effects of temperature on the shell growth of young Mytilus edulis L. J. Exp. Mar. Biol. Ecol. 59, 275-288.

Amouroux J.M., 1984, Preliminary study on the consumption of dissolved organic matter (exudates) of bacteria and phytoplankton by the marine bivalve Venus verrucosa. Mar. Biol. 82, 109-112.

Arneri E., Giannetti G., Antolini B., 1998, Age determination and growth of Venus verrucosa L. (Bivalvia: Veneridae) in the southern Adriatic and the Aegean Sea. Fish. Res. 38, 193-198.

Barbin L., Boarini I., Borasio P.G., Barion P., Fiorini S., Rossi R., Biondi C., 2003, Nitric oxide-mediated arachidonic acid release from perifused Venus verrucosa oocytes. Gen. Comp. Endocrinol. 130, 215-221. 
Bayne B.L., 2004, Phenotypic flexibility and physiological tradeoffs in the feeding and growth of marine bivalve molluscs. Integr. Comp. Biol. 44, 425-432.

Belicka L.L., Sokol E.R., Hoch J.M., Jaffé R., Trexler J.C., 2012, A molecular and stable isotopic approach to investigate algal and detrital energy pathways in a freshwater marsh. Wetlands 32 , 531-542.

Bligh E.G., Dyer W.J., 1959, A rapid method of total lipid extraction and purification. Can J. Biochem. Physiol. 37, 911-917

Blott S.J., Pye K., 2001, GRADISTAT: A grain size distribution and statistics package for the analysis of unconsolidated sediments. Earth Surf. Process. Landforms 26, 1237-1248

CNROP, 1993, Fisheries and stock evaluation in Mauritania: avenues for development and management. Report of the 3rd Working Group of CNROP, Nouadhibou, Mauritania. http://hdl.handle. net/1834/1246.

Cranford P.J., Grant J., 1990, Particle clearance and absorption of phytoplankton and detritus by the sea scallop Placopecten magellanicus (Gmelin). J. Exp. Mar. Biol. Ecol. 137, 105-121.

Dalsgaard J., St John M., Kattner G., Muller-Navarra D., Hagen W., 2003, Fatty acid trophic markers in the pelagic marine environment. Adv. Mar. Biol. 46, 225-340.

Dame R.F., 1996, Ecology of marine bivalves: an ecosystem approach, Boca Raton, CRC Press.

Dang C., de Montaudouin X., Gam M., Paroissin C., Bru N., CaillMilly N., 2010, The Manila clam population in Arcachon Bay (SW France) : Can it be kept sustainable? J. Sea Res. 63, $108-118$.

De Montaudouin X., 1996, Factors involved in growth plasticity of cockles Cerastoderma edule (L), identified by field survey and transplant experiments. J. Sea Res. 36, 251-265.

Djabali F., Yahiaoui M., 1978, La praire (Venus verrucosa L.) en rade de Brest et en baie de Granville : biologie - production - exploitation. Thèse Université de Bretagne Occidentale, Brest.

El-Menif N.T., Guezzi Y., Lahbib Y., Ramdani M., Flower R., 2008, Effects of biogenic concretions, epibionts, and endobionts on the relative growth of the clam Venus verrucosa in Bizerta Lagoon, Tunisia. J. Shellfish Res. 27, 1087-1092.

Ezgeta-Balic D., Najdek M., Peharda M., Blazina M., 2012, Seasonal fatty acid profile analysis to trace origin of food sources of four commercially important bivalves. Aquaculture 334, 89-100.

Fredriksen S., 2003, Food web studies in a Norwegian kelp forest based on stable isotope $\left(\delta^{13} \mathrm{C}\right.$ and $\left.\delta^{15} \mathrm{~N}\right)$ analysis. Mar. Ecol. Prog. Ser. 260, 71-81.

Gaillard B., 2010, Gestion d'une espèce à haute valeur patrimoniale dans l'archipel des îles Chausey : rôles respectifs des contraintes environnementales et anthropiques dans la dynamique des populations de la praire Venus verrucosa (L., 1758). Gestion des écosystèmes marins et côtiers. Université du Littoral Côte d'Opale de Calais, USTL, Lille, Master 2 Pro

Gillmor R.B., 1982, Assessment of intertidal bivalve growth and capacity adaptations in suspension-feeding bivalves. Mar. Biol. 68, 277-286.

Glover E.A., Taylor J.D., 2010, Needles and pins: acicular crystalline periostracal calcification in venerid bivalves (Bivalvia: Veneridae). J. Mollus. Stud. 76, 157-179.

Godet L., 2008, L'évaluation des besoins de conservation d'un patrimoine naturel littoral marin: l'exemple des estrans meubles de l'archipel de Chausey. Thèse, Muséum National d'Histoire Naturelle, Paris.

Godet L., Toupoint N., Fournier J., Le Mao P., Retiere C., Olivier F., 2009, Clam farmers and oystercatchers: effects of the degradation of Lanice conchilega beds by shellfish farming on the spatial distribution of shorebirds. Mar. Pollut. Bull. 58, 589-595.
Gollety C., Riera P., Davoult D., 2010, Complexity of the food web structure of the Ascophylum nodosum zone evidenced by a $\delta^{13} \mathrm{C}$ and $\delta^{15} \mathrm{~N}$ study. J. Sea Res. 64, 304-312.

Gosling E., 2003, Bivalve molluscs: Biology, Ecology and Culture, Oxford, Blackwell Publishing Ltd.

Gunsen U., Aydin A., Ozcan A., 2008, Determination of the toxin profile of Venus gallina, Venus verrucosa and Cardium edule mussels in Turkey. Arch. Lebensmittelhyg. 59, 233-238.

Higgins R.P., Thiel H., 1988, Introduction to the study of meiofauna, Washington, DC, Smithsonian Institution Press.

Jeffrey S.W., Mantoura R.F.C., Whright S.W., 1997, Phytoplankton pigments in oceanography: guidelines to modern methods, Paris, UNESCO.

Kelly J.R., Scheibling R.E., 2012, Fatty acids as dietary tracers in benthic food webs. Mar. Ecol. Prog. Ser. 446, 1-22.

Lami R., 1972, Florule algologique des Iles Chausey par Gontran Hamel. Bull. Lab. Marit. Dinard 1, 225-241.

Le Berre S., Brigand L., 2011, La pêche à pied dans l'archipel de Chausey (France) : contribution à une analyse des politiques de gestion durable de l'estran à travers la prise en compte des activités récréatives. In: Tagliani F. (Ed) Insularité et développement durable, Brest, IRD, Coll. Objectifs Sud, pp.149-167.

Lorrain A., Paulet Y.M., Chauvaud L., Savoye N., Donval A., Saout C., 2002, Differential delta C-13 and delta N-15 signatures among scallop tissues: implications for ecology and physiology. J. Exp. Mar. Biol. Ecol. 275, 47-61.

McCutchan J.H., Lewis W.M., Kendall C., McGrath C.C., 2003, Variation in trophic shift for stable isotope ratios of carbon, nitrogen, and sulfur. Oikos 102, 378-390.

Meyers P.A., 1997, Organic geochemical proxies of paleoceanographic, paleolimnologic, and paleoclimatic processes. Org. Geochem. 27, 213-250.

Meziane T., Tsuchiya M., 2002, Organic matter in a subtropical mangrove-estuary subjected to wastewater discharge: Origin and utilisation by two macrozoobenthic species. J. Sea Res. 47, 1-11.

Michener R.H., Kaufman L., 2007, Stable isotope ratios as tracers. In: Michener R.H., Lajtha K. (Eds.) Stable isotopes in ecology and environmental science. Blackwell, Malden, pp. 238-282.

Miller R.J., Page H.M., 2012, Kelp as a trophic resource for marine suspension feeders: a review of isotope-based evidence. Mar. Biol. 159, 1391-1402.

Mortillaro J.M., Abril G., Moreira-Turcq P., Sobrinho R.L., Perez M., Meziane T., 2011, Fatty acid and stable isotope $\delta^{13} \mathrm{C}$ and $\delta^{15} \mathrm{~N}$ signatures of particulate organic matter in the lower Amazon River: Seasonal contrasts and connectivity between floodplain lakes and the mainstem. Org. Geochem. 42, 1159-1168.

Morton B., Peharda M., Petric M., 2011, Functional morphology of Rocellaria dubia (Bivalvia: Gastrochaenidae) with new interpretations of crypt formation and adventitious tube construction, and a discussion of evolution within the family. Biol. J. Linn. Soc. 104, 786-804.

Nerot C., Lorrain A., Grall J., Gillikin D.P., Munaron J.M., Le Bris H., Paulet Y.M., 2012, Stable isotope variations in benthic filter feeders across a large depth gradient on the continental shelf. Estuar. Coast. Shelf Sci. 96, 228-235

Pasquale V., Romano V., Rupnik M., Capuano F., Bove D., Aliberti F., Krovacek K., Dumontet S., 2012, Occurrence of toxigenic Clostridium difficile in edible bivalve molluscs. Food Microbiol. 31, 309-312.

Pauly D., Munro J.L., 1984, Once more on the comparison of growth in fishes and invertebrates. Fishbyte 2, 21-22

Peharda M., Ezgeta-Balic D., Vrgoc N., Isajlovic I., Bogner D., 2010, Description of bivalve community structure in the Croatian part 
of the Adriatic Sea - hydraulic dredge survey. Acta Adriat. 51, 141-158.

Pernet F., Gauthier-Clerc S., Mayrand É., 2007, Change in lipid composition in eastern oyster (Crassostrea virginica Gmelin) exposed to constant or fluctuating temperature regimes. Comp. Biochem. Physiol. 147, 557-565.

Peterson B.J., Fry B., 1987, Stable isotopes in ecosystem studies. Annu. Rev. Ecol. Syst. 18, 293-320.

Pitel M., Berthou P., Fifas S., 2001, Caractéristiques de dragues et pêcheries. Ifremer Rep., Brest.

Pitel-Roudaut M., Martin S., Fifas S., Huet J., Berthou P., 2006, Évaluation du stock de praires en rade de Brest. Ifremer Rep. Brest.

Poppe G.T., Goto Y., 1993, European seashells. Volume 2 (Scaphopoda, Bivalvia, Cephalopoda). Wiesbaden, Verlag Christa Hemmen.

Post D.M., 2002, Using stable isotopes to estimate trophic position: Models, methods, and assumptions. Ecology 83, 703-718.

Quinn G.P., Keough M.J., 2002, Experimental design and data analysis for biologists, Cambridge, Cambridge University Press.

Richardson C.A., Crisp D.J., Runham N.W., 1980, Factors influencing shell growth in Cerastoderma edule. Proc. R. Soc. Lond. B. Biol. 210, 513-531.

Riera P., Stal L., Nieuwenhuize J., 2004, Utilization of food sources by invertebrates in a man-made intertidal ecosystem (Westerschelde, the Netherlands): a $\delta^{13} \mathrm{C}$ and $\delta^{15} \mathrm{~N}$ study. J. Mar. Biol. Assoc. UK 84, 323-326.

Romeo M., Gnassia-Barelli M., 1988, Donax trunculus and Venus verrucosa as bioindicators of trace-metal concentrations in Mauritanian coastal waters. Mar. Biol. 99, 223-227.

Ronconi R.A., Koopman H.N., McKinstry C.A.E., Wong S.N.P., Westgate A.J., 2010, Inter-annual variability in diet of nonbreeding pelagic seabirds Puffinus spp. at migratory staging areas: evidence from stable isotopes and fatty acids. Mar. Ecol. Prog. Ser. 419, 267-282.

Royer C., Thébault J., Chauvaud L., Olivier F., 2013, Structural analysis and paleoenvironmental potential of dog cockle shells (Glycymeris glycymeris) in Brittany, northwest France. Palaeogeogr. Paleoclim. Paleoecol. 373, 123-132.
Rufino M.M., Gaspar M.B., Pereira A.M., Maynou F., Monteiro C.C., 2010, Ecology of megabenthic bivalve communities from sandy beaches on the south coast of Portugal. Sci. Mar. 74, 163-178.

Siniscalchi A., Cavallini S., Sonetti D., Sbrenna G., Capuano S., Barbin L., Turolla E., Rossi R., 2004, Serotonergic neurotransmission in the bivalve Venus verrucosa (Veneridae): a neurochemical and immunohistochemical study of the visceral ganglion and gonads. Mar. Biol. 144, 1205-1212.

Sokal R.R., Rohlf F.J., 1995, Biometry: The principles and practice of statistics in biological research. New York, 3rd edition, W.H. Freeman.

Thompson R.J., 1984, Production, reproductive effort, reproductive value and reproductive cost in a population of the blue mussel Mytilus edulis from a subarctic environment. Mar. Ecol. Prog. Ser. 16, 249-257.

Tirado C., Salas C., Marquez I., 2003, Reproduction of Venus verrucosa L., 1758 (Bivalvia: Veneridae) in the littoral of Malaga (southern Spain). Fish. Res. 63, 437-445.

Toupoint N., Godet L., Fournier J., Retière C., Olivier F., 2008, Does Manila clam cultivation affect habitats of the engineer species Lanice conchilega (Pallas, 1766)? Mar. Pollut. Bull. 56, 1429-1438.

Trigui El-Menif N., Guezzi Y., Le Pennec M., Boumaiza M., Le Pennec G., 2005, Infestation of the clam Venus verrucosa by Sipunculoidea and the lithophagus bivalve, Gastrochaena dubia. Acta Adrat. 46, 83-90.

Tucker M.J., Pitt E.G., 2001. Waves in Ocean Engineering. Elsevier Science.

Urban H.J., 1994, Adaptations of six infaunal bivalve species of Chile: Coexistence resulting from differences in morphology, burrowing depth and substrate preference. Arch. Fish. Mar. Res. 42, 183-193.

Vogel S., 1984, Drag and flexibility in sessile organisms. Am. Zool. 24, 37-44.

Wildish D., Kristmanson D., 2005, Benthic suspension feeders and flow. New York, Cambridge University Press

Wildish D.J., Saulnier A.M., 1993, Hydrodynamic control of filtration in Placopecten magellanicus. J. Exp. Mar. Biol. Ecol. 174, 65-82. 